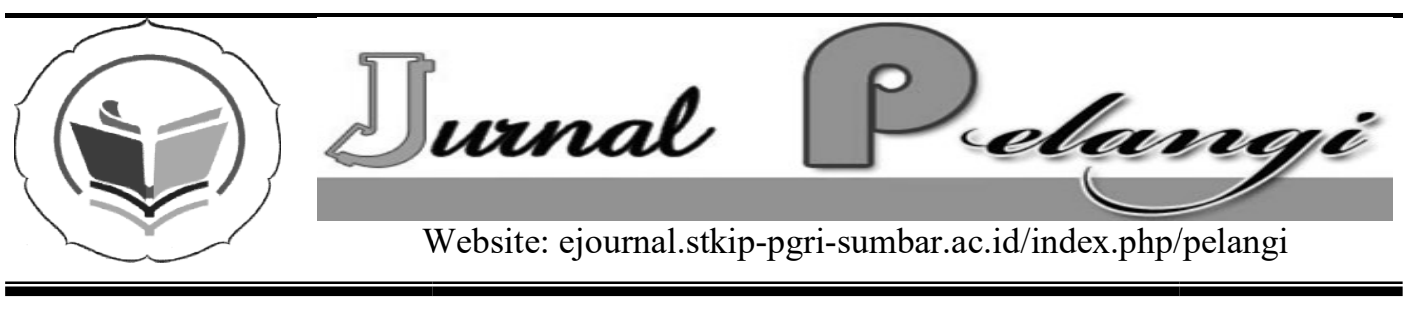

\title{
PENGARUH MEDIA REALIA TERHADAP PRESTASI BELAJAR MATEMATIKA SISWA KELAS X SMK
}

\author{
Mira Hastin \\ Sekolah Tinggi Keguruan dan Ilmu Pendidikan (STKIP) Muhammadiyah \\ Wilayah Jambi - Sungai Penuh \\ hastinmira@gmail.com
}

\section{INFO ARTIKEL}

Diterima:

10 April 2016

Direview:

20 Mei 2016

Disetujui:

25 Juni 2016

Kata Kunci:

Media Realia, Prestasi Belajar

\section{Keywords:}

Realia Media,

Learning Achievement

\begin{abstract}
Abstrak
Penelitian ini bertujuan untuk mengetahui apakah terdapat pengaruh media realia terhadap prestasi belajar matematika siswa kelas X SMK N 3 Sungai Penuh Tahun Pelajaran 2013/2014. Jenis penelitian ini adalah deskriptif dengan populasi adalah seluruh siswa kelas X Busana SMK N 3 Sungai Penuh. Teknik penegambilan sampel yang dilakukan adalah teknik simple random sampling, kelas $\mathrm{XB}_{2}$ yang jumlah siswanya 22 orang terpilih sebagai kelas sampel. Pengumpulan data dalam penelitian ini menggunakan angket dan tes hasil belajar. Uji coba angket dilakukan di SMK N 3 Sungai Penuh. Hasil analisis data menunjukkan bahwa persamaan regresi yang diperoleh yaitu $\hat{Y}=-34,52+1,41 X$. Kemudian dilanjutkan dengan uji linieritas, didapatkan $F_{\text {hitung }}$ $=0,05$ sedangkan $F_{\text {tabel }}=2,90$. Karena $F_{\text {hitung }}<F_{\text {tabel }}$ berarti persamaan regresi adalah linier dan regresi berarti secara nyata pada taraf $95 \%$. Harga koefisien korelasi yang diperoleh adalah 0,499 dan koefisien determinasi adalah 0,249 atau 25\%. Ini berati bahwa terdapat pengaruh media realia terhadap prestasi belajar matematika siswa.
\end{abstract}

\begin{tabular}{l} 
Abstract \\
This research was aimed to find out the effect of realia media \\
toward students' learning achievement in learning math at \\
grade X of SMK N 3 Sungai Penuh in 2013/2014 academic \\
year. It was designed as descriptive research. The population \\
was the entire Fashion Class of grade X of SMK $N 3$ Sungai \\
Penuh. The sample was selected by using random sampling \\
technique. The 22 students of grade XB2 was selected as the \\
sample. The data was collected by using questionnaire and the \\
achievement test. The questionnaire was tried out at SMK $N 3$ \\
Sungai Penuh. The result of regression equation from data \\
analysis showed that $\hat{Y}=-34.52+1.41 X$. Then, the linearity \\
test showed that $F_{\text {count }}=0.05$ and $F_{\text {table }}=2.90$. Due to the fact \\
\hline
\end{tabular}


that $F_{\text {count }}<F_{\text {table, }}$ regression equation was linier and regressive in which factually on the range of $95 \%$. The value of correlation coefficient was 0.449 and determination coefficient was 0.249 or $25 \%$. Thus, it can be concluded that there was significant effect of realia medium toward students' learning achievement in learning math.

\section{PENDAHULUAN}

Matematika merupakan salah satu mata pelajaran yang perlu diberikan di setiap jenjang pendidikan, mulai dari pendidikan dasar sampai ke tingkat perguruan tinggi. Hal ini karena peranan matematika sangat penting dalam kehidupan sehari-hari dan bagi perkembangan ilmu pengetahuan dan teknologi.

Peranan matematika mencakup seluruh aspek kehidupan, yang tidak hanya terbatas pada ilmu pengetahuan alam saja, tetapi matematika juga mempunyai peranan penting dalam ilmu teknik, sosial dan budaya. Mengingat begitu pentingnya matematika, maka pemerintah Indonesia terus berusaha untuk meningkatkan mutu pengajaran matematika, buktinya dapat dilihat dari kurikulum yang terus diperbaharui, nilai rata-rata kelulusan siswa yang semakin meningkat, penyediaan sarana dan prasarana yang lengkap untuk menunjang pembelajaran matematika, dan usaha yang dilakukan guru untuk meningkatkan motivasi siswa-siswa untuk selalu belajar dengan baik, karena proses belajar mengajar merupakan salah satu faktor yang menentukan berhasilnya siswa dalam belajar.

Hal ini menjadi harapan semua pihak agar setiap siswa dapat mencapai hasil belajar dengan sebaik-baiknya sesuai dengan hasil yang diharapkan sesuai dengan kemampuan masingmasing. Tetapi dalam kenyataannya, tidak semua siswa dapat mencapai hasil belajar yang baik, hal ini disebabkan oleh siswa-siswa tidak bisa memahami pelajaran dengan baik.

Pembelajaran pada dasarnya, merupakan suatu proses komunikasi, yaitu proses penyampaian pesan dari sumber pesan melalui saluran/media tertentu ke penerima pesan. Pesan, sumber pesan, saluran/media dan penerima pesan adalah komponenkomponen proses komunikasi. Pesan yang akan dikomunikasikan adalah isi ajaran ataupun didikan yang ada dalam kurikulum, sumber pesannya bisa guru, siswa, orang lain atau pun penulis buku dan prosedur media.

Berdasarkan hasil observasi dan wawancara guru matematika di SMK Negeri 3 Sungai Penuh, terlihat banyak siswa yang masih mendapatkan nilai dibawah Kriteria Ketuntasan Maksimum (KKM) yang telah ditetapkan yaitu 76 . Selain dari itu banyak terlihat murid yang kurang menyukai pelajaran matematika.

Rendahnya pencapaian nilai siswa menjadi indikasi bahwa pembelajaran yang dilakukan belum efektif. Salah satu penyebabnya adalah metode belajar yang digunakan oleh guru krurang melibatkan keaktifan murid dan juga kurangnya kepedulian dari guru untuk memberikan media dalam pembelajaran. Selama ini guru hanya menggunakan metode mencatat di papan tulis dan tanya jawab dalam pembelajaran. Guru hanya menjelaskan materi pelajaran, memberi contoh soal dan dilanjutkan dengan memberikan soal latihan tanpa menggunakan benda contoh pada pelajaran yang memerlukan benda nyata sebagai contohnya. Hal ini tentu saja 
menjadikan siswa jenuh dalam pelajaran, karena kurangnya variasi dari guru dalam mengajar. Sehingga tidak sedikit siswa yang bosan dan kurang mau mengikuti materi pembelajaran matematika.

Penggunaan media realia dalam pembelajaran matematika diharapkan dapat membuat siswa lebih aktif lagi dalam pembelajaran. Siswa juga bisa dengan mudah memahami materi pelajaran karena menggunakan media dalam pembelajaran. Dan diharapkan juga dengan pembelajaran yang menggunakan media realia pelajarn menjadi menyenangkan karena adanya keaktifan dari para siswa sehingga materi tersebut lebih mudah dipahami. Berdasarkan uraian diatas, masalah yang akan diselesaikan adalah apakah terdapat pengaruh dan seberapa besar pengaruh media realia terhadap peningkatan prestasi belajar matematika siswa kelas $X$ SMK Negeri 3 Sungai Penuh.

\section{METODE PENELITIAN}

Jenis penelitian ini adalah penelitian deskriptif untuk memberi uraian mengenai fenomena atau gejala sosial yang diteliti dengan mendeskripsikan tentang nilai variabel mandiri, baik satu variabel atau lebih (independent) berdasarkan indikator-indikator dari variabel yang diteliti tanpa membuat perbandingan atau menghubungkan antar variabel yang diteliti guna untuk eksplorasi dan klasifikasi dengan mendeskripsikan sejumlah variabel yang berkenaan dengan masalah variabel yang diteliti.

Populasi dalam penelitian ini adalah siswa kelas X SMK Negeri 3 Sungai Penuh yang berjumlah 43 orang, terdiri dari 21 orang kelas $\mathrm{X} \mathrm{B}_{1}$ dan 22 orang kelas $B_{2}$. Pengambilan sampel dilakukan secara acak, karena dari hasil uji normalitas, uji homogenitas variansi dan uji kesamaan rata-rata diperoleh bahwa populasi normal, homogen dan memiliki kesamaan rata-rata. Terpilihlah kelas sampel adalah kelas $\mathrm{XB}_{2}$ yang berjumlah 22 orang.

Instrumen dalam penelitian ini menggunakan angket dan tes hasil belajar matematika. Analisis regresi digunakan untuk mendapatkan hubungan fungsional antara dua variabel atau lebih Sudjana (2005: 315). Sebelum dilakukan analisis regresi data setiap variabel yang akan dianalisis harus berdistribusi normal (Sugiyono, 2010:241). Untuk itu sebelum pengujian hipotesis dilakukan, maka terlebih dahulu akan dilakukan pengujian normalitas data dengan mengunakan uji Lilliefors. Selanjutnya menentukan persamaan regresi untuk melihat pengaruh media realia (X) terhadap prestasi belajar matematika (Y) yang dapat dilakukan dengan analisis regresi linear sederhana.. Persamaan regresi linear sederhana seperti berikut ini:

$\hat{Y}=\mathrm{a}+\mathrm{bX}$

Harga a dan b diperoleh dengan rumus:

$$
\begin{aligned}
& \mathrm{a}=\frac{\left(\sum Y_{i}\right)\left(\sum X_{i}^{2}\right)-\left(\sum X_{i}\right)\left(\sum X_{i} Y_{i}\right)}{n \sum X_{i}^{2}-\left(\sum X_{i}\right)^{2}} \\
& \mathrm{~b}=\frac{n\left(\sum X_{i} Y_{i}\right)-\left(\sum X_{i}\right)\left(\sum Y_{i}\right)}{n \sum X_{i}^{2}-\left(\sum X_{i}\right)^{2}}
\end{aligned}
$$

Keterangan :

$\begin{array}{ll}\mathrm{n} & =\text { Jumlah sampel } \\ \mathrm{X}_{\mathrm{i}} & =\text { Skor pengaruh media realia } \\ \mathrm{Y}_{\mathrm{i}} & =\text { Skor prestasi belajar } \\ & \text { matematika }\end{array}$

Setelah diperoleh persamaan regresi, kemudian dilakukan uji linieritas dan uji keberartian regresi. Dengan tujuan untuk mengetahui keterkaitan antara variabel dalam persamaan regresi serta untuk mengetahui apakah model regresi linier yang digunakan cocok atau tidak. Teknik korelasi ini digunakan untuk mencari pengaruh media realia $(\mathrm{X})$ terhadap prestasi belajar siswa (Y). Untuk menghitung koefisien korelasi 
berdasarkan data yang telah diperoleh dengan teknik Product Moment dikemukakan oleh Sugiyono (2009:228) sebagai berikut:

$$
\frac{\mathrm{r}_{\mathrm{xy}}=}{n \sum X_{i} Y_{i}-\left(\sum X_{i}\right)\left(\sum Y_{i}\right)} \frac{\sqrt{\left\{n \sum X_{i}^{2}-\left(\sum X_{i}\right)^{2}\right)\left(n \sum Y_{i}^{2}-\left(\sum Y\right)^{2}\right.}}{}
$$

Keterangan:

$r_{X Y}=$ Koefisien korelasi

$\sum X=$ Jumlah skor variabel $\mathrm{X}$

$\sum Y=$ Jumlah skor variabel $\mathrm{Y}$

$\sum X Y=$ Jumlah hasil kali variabel $\mathrm{X}$ dan variabel Y

$\sum X^{2}=$ Jumlah kuadrat skor variabel $\mathrm{X}$ $\sum Y^{2}=$ Jumlah kuadrat skor variabel $Y$ $n=$ besar sampel

Koefisien determinasi yang diperoleh $\left(\mathrm{r}^{2}\right)$ dinyatakan dalam \% untuk melihat besarnya pengaruh media realia dalam belajar matematika.

\section{HASIL DAN PEMBAHASAN}

Pengumpulan data dalam penelitian ini menggunakan angket dan tes hasil belajar. Uji coba angket dilakukan di SMKN 3 Sungai Penuh. Kemudian menganalisis hasil uji coba angket dan soal. Dalam penelitian ini disebarkan angket dan tes hasil belajar pada kelas X. Dari hasil penyebaran angket dan pemberian tes hasil belajar matematika kepada siswa kelas $\mathrm{XB}_{2}$ dengan jumlah sampel 22 orang. Diperoleh data mengenai pengaruh media realia yang dilambangkan dengan (X) dan hasil belajar matematika siswa yang dilambangkan dengan (Y). Data hasil penyebaran angket disajikan pada Tabel 1.

Berdasarkan Tabel 1, dapat diketahui bahwa pengaruh media realia terhadap siswa dalam proses pembelajaran matematika sudah cukup baik. Dalam belajar matematika siswa sudah ada yang senang dengan penggunaan media realia selama pembelajaran, sehingga siswa disiplin dalam belajar. Akan tetapi masih banyak juga siswa yang kurang bisa memerima atau merespon dan mengerti akan materi matematika yang diterangkan guru menggunakan media tersebut dengan baik. Karena siswa lebih banyak memperhatikan media-media yang digunakan dari pada me mmahami maksud atau hubungan media yang digunakan oleh guru matematika. Dalam penelitian ini terlihat juga siswa yang mengerjakan tugas, mengulang pelajaran dirumah siswa melakukannya apabila diberikan PR dan akan diadakan tes matematika di sekolah.

Tabel 1. Tabulasi Skor Angket di Kelas $\mathrm{XB}_{2}$ SMK 3 Sungai Penuh

\begin{tabular}{|c|c|c|c|c|c|}
\hline $\begin{array}{c}\text { Jumlah } \\
\text { Siswa }\end{array}$ & $\begin{array}{c}\text { Jumlah } \\
\text { Item }\end{array}$ & $\begin{array}{c}\text { Skor } \\
\text { Rata-Rata }\end{array}$ & $\begin{array}{c}\text { Standar } \\
\text { Deviasi }\end{array}$ & $\begin{array}{c}\text { Skor } \\
\text { Maks }\end{array}$ & $\begin{array}{c}\text { Skor } \\
\text { Min }\end{array}$ \\
\hline 22 & 23 & 75,41 & 4,36 & 85 & 65 \\
\hline
\end{tabular}

Tabel 2. Daftar Tabulasi Skor Hasil Belajar Matematika Kelas $\mathrm{XB}_{2}$ SMK Negeri 3 Sungai Penuh

\begin{tabular}{|c|c|c|c|c|c|c|c|}
\hline \multirow{2}{*}{$\begin{array}{c}\text { Jumlah } \\
\text { Siswa }\end{array}$} & \multirow{2}{*}{$\begin{array}{c}\text { Jumlah } \\
\text { Soal }\end{array}$} & \multirow{2}{*}{$\begin{array}{c}\text { Skor } \\
\text { Rata-rata }\end{array}$} & \multirow{2}{*}{$\begin{array}{c}\text { Standar } \\
\text { Deviasi }\end{array}$} & \multicolumn{2}{|c|}{ Skor } & \multicolumn{2}{|c|}{ Nilai Siswa } \\
\cline { 5 - 8 } & & Max & Min & $\geq \mathbf{6 1}$ & $<\mathbf{6 1}$ \\
\hline 22 & 8 & 72,73 & 13,36 & 87,5 & 50 & 19 orang & 3 orang \\
\hline
\end{tabular}


Tabel 3. Hasil Analisis Korelasi Product Moment

\begin{tabular}{|c|c|c|}
\hline \multirow{2}{*}{ Variabel Bebas } & \multicolumn{2}{|c|}{ Variabel Terikat : Hasil Belajar (Y) } \\
\cline { 2 - 3 } & $\boldsymbol{r}_{\boldsymbol{X}}$ & $\boldsymbol{r}_{\text {tabel }}$ \\
\hline Angket madia realia (X) & 0,499 & 0,423 \\
\hline
\end{tabular}

Data mengenai hasil belajar matematika siswa berdasarkan tes hasil belajar terlihat pada Tabel 3. Dari Tabel 3 terlihat bahwa tes yang penulis berikan kepada 22 orang sampel diperoleh informasi bahwa banyak siswa belum mencapai KKM pada materi bilangan riil untuk kelas $\mathrm{XB}_{2}$ semester 1 dengan soal 8 buah. Rata-rata hasil belajar siswa adalah 72,73. Ini berarti rata-rata siswa sudah memahami materi pelajaran matematika dengan baik.

Pada bagian ini dibahas mengenai proses untuk memperoleh persamaan regresi linier sederhana, uji normalitas, uji linieritas dan keberartian koefisien regresi sederhana, koefisien korelasi dan koefisien determinasi.

Model persamaan regresi linier sederhana adalah $\hat{Y}=a+b X$. Dari hasil penelitian didapat harga $a=-34,52$ dan $\mathrm{b}=1,41$ sehingga persamaan regresi linier sederhana yang diperoleh adalah $\hat{Y}$ $=-34,52+1,41$ X. Dalam uji normalitas akan diuji hipotesis bahwa data angket belajar dengan media realia dan prestasi belajar berdistribusi normal atau tidak. Uji normalitas angket berdasarkan hasil perhitungan diperoleh harga $L_{0}=$ 01014, sedangkan $L_{\text {tabel }}=0,179$. Jadi, $L_{0}<L_{\text {tabel }} \quad$ yaitu $0,1014<0,179$ untuk taraf nyata $95 \%$. Dan uji normalitas prestasi belajar berdasarkan hasil peritungan diperoleh harga $L_{0}=0,1733$ sedangkan $L_{\text {tabel }}=0,179$. Jadi, $L_{0}<L_{\text {tabel }}$ yaitu $0,1733<0,179$ untuk taraf nyata $95 \%$ sehingga didapatkan kesimpulan bahwa data angket media realia dan data prestasi belajar berasal dari data yang berdistribusi normal. Untuk linieritas regresi dari hasil perhitungan diperoleh harga $\mathrm{F}_{\text {hitung }}=0,05$ dan harga
$F_{(0,05)(11,9)=2,90}$ Karena $\mathrm{F}$ hitung $<\mathrm{F}$ tabel maka regresi tersebut linier pada taraf signifikan $95 \%$, atau terdapat hubungan linier antara variabel $\mathrm{X}$ dan variabel $\mathrm{Y}$.

Teknik korelasi product moment bertujuan untuk melihat sejauh mana arah hubungan salah satu variabel bebas dengan variabel terikat. Sedangkan variabel bebas dalam penelitian ini adalah media realia (X) dan variabel terikat adalah prestasi belajar matematika siswa kelas $\mathrm{XB}_{2}$ SMK 3 Sungai Penuh (Y). Berdasarkan data yang diolah, diperoleh hasil untuk analisis korelasi product moment pada Tabel 4. Dari Tabel 4 jelas terlihat bahwa $r_{\text {hitun }}>r_{\text {tabel }}$, dan dari perhitungan yang dilakukan didapat harga $r=0,499$ karena harga $r$ positif maka terdapat pengaruh yang positif antara media realia terhadap prestasi belajar matematika dengan interprestasi sangat rendah. Dan koefisien determinasi $(r)^{2}=0,25$. Jadi besarnya hubungan variabel $\mathrm{X}$ terhadap Variabel $\mathrm{Y}$ adalah $25 \%$. Ini berarti bahwa pengaruh media realia terhadap prestasi belajar matematika sebesar $25 \%$.

Pada saat penelitian penulis membagikan 22 buah angket dan tes soal kepada siswa kelas $\mathrm{XB}_{2}$ SMK Negeri 3 Sungai Penuh. Pada saat pengisian angket ada siswa yang serius mengerjakannya sendiri, dan juga ada siswa yang bertanya kepada temannya sehingga menganggu teman lain yang serius mengisi angket. Melihat hal tersebut penulis memberi tahu bahwa angket tersebut diisi sendiri-sendiri dan angket tersebut tidak akan mempengaruhi nilai hasil belajar siswa. Pada saat mengerjakan tes soal tentang 
materi Fungsi, ada beberapa siswa yang mencontoh sehingga menganggu konsentrasi teman yang lainnya. Melihat hal tersebut penulis mengawasi siswa yang mencontoh tersebut agar tidak menganggu teman yang lainnya.

Dari hasil pengisian angket tentang cara belajar matematika kepada 22 orang siswa kelas $\mathrm{XB}_{2}$ diperoleh informasi bagaimana pengaruh media realia siswa yang ingin penulis lihat, yang sesuai dengan indikator angket yang akan diteliti. Berdasarkan respon siswa yang diungkapkan lewat angket yang diberikan kepada siswa, diperoleh temuan bahwa sikap siswa terhadap pembelajaran dengan menggunakan media realia yang menekankan kemampuan pemecahan masalah pada materi pelajaran matematika selama penelitian berlangsung adalah positif.

Hal ini secara jelas dapat dilihat dari skor rata-rata tiap item angket siswa lebih besar daripada skor sikap netral yaitu 3. Dari jawaban siswa dapat diketahui bahwa pada pembelajaran yang dikembangkan terlihat motivasi siswa dalam belajar adalah tinggi, sehingga mereka mau bekerja keras dalam menyelesaikan tugas walaupun belum mencapai hasil maksimal. Sebagai implementasinya, siswa dapat merasakan bahwa aktivitas pembelajaran dengan menggunakan media realia yang menekankan pada kemampuan pemahaman materi lebih mendalam dan berhubungan dengan kehidupan seharihari mempengaruhi perilaku mereka ketika belajar yang disajikan dengan menggunakan media realia. Dan hal ini berarti dapat mendorong siswa dalam menyelesaikan masalah yang dihadapi melalui cara-cara yang dapat dimengerti. Demikian juga siswa dapat merasakan kebermaknaan belajar dengan menggunakan media terutama media realia.
Pembelajaran ini juga dapat
memberikan sumbangan dalam
mengembangkan pemecahan masalah siswa dibandingkan pembelajaran konvensional. Hal ini dapat diketahui dari jawaban siswa yang menyatakan lebih menyenangi cara belajar seperti yang diberikan dan mereka merasa terbantu untuk mengemukakan pendapat, berpikir secara nyata.

Aktivitas siswa selama pembelajaran dengan menggunakan media realia berdasarkan dari hasil pengamatan pada aspek yang diamati yaitu: mengemukakan masalah autentik tentang masalah-masalah matematika yang berhubungan dengan yang ada di sekitar siswa, mengajukan pertanyaan/ mengemukakan pendapat, penyelesaian tugas, keaktifan anggota dalam kelas, menyajikan hasil karya, secara keseluruhan memberikan gambaran bahwa pembelajaran dengan menggunakan media realia telah menciptakan kondisi siswa aktif dan suasana belajar yang menyenangkan. Aktivitas siswa membuat siswa menjadi lebih kreatif.

Setelah pembelajaran menggunakan media realia terlihat prestasi belajar siswa meningkat. Permasalahan atau soal-soal yang diberikan mampu diselesaikan siswa dengan maksimal. Maka dapat di katakana bahwa pengaruh media realia terhadap hasil belajar siswa sangat baik. Walaupun masih ada beberapa hal yang menjadi kendala selama penelitian ini berlangsung, diantaranya dalam membuat beberapa media belajar yang membutuhkan keterampilan dan waktu yang lama, menyesuaikan media yang digunakan dengan materi yang akan dibahas setiap pertemuannya. Tetapi walaupun banyak kendala-kendala seperti yang di sampaikan tetap saja respon siswa terhadap penggunaan media realia sangat 
baik, belajar lebih menyenangkan dengan adanya peragaan langsung oleh guru di depan kelas dengan menggunakan media.

\section{KESIMPULAN}

Berdasarkan hasil analisis dan pembahasan data yang telah dikemukakan sebelumnya, maka dapat diambil kesimpulan: Terdapat pengaruh media realia terhadap prestasi belajar matematika siswa kelas $\mathrm{XB}_{2} \quad \mathrm{SMK}$ Negeri 3 Sungai Penuh. Pengaruh media realia terhadap prestasi belajar matematika siswa kelas X SMK Negeri 3 Sungai Penuh adalah sebesar 25\%.

\section{UCAPAN TERIMA KASIH}

Terbitnya tulisan ini tidak terlepas dari bantuan berbagai pihak, untuk itu penulis ucapkan terima kasih yang sebesar-besarnya kepada Pihak STKIP PGRI Sumatera Barat khususnya pengelola jurnal Pelangi yang telah memberikan kesempatan kepada penulis untuk menulis di Jurnal Pelangi. Selanjutnya penulis juga berterima kasih kepada para penyumbang sumber inspirasi yang telah memberikan inspirasi bagi penulis untuk mengutip atau menggunakan tulisannya sebagai bahan referensi.

\section{DAFTAR PUSTAKA}

Arikunto, Suharsimi. 2010. Prosedur Penelitian. Jakarta: Rineka Cipta

Lestari, Novita, Eka. 2014. Pengaruh Penggunaan Media Realia Terhadap Keaktifan Belajar Siswa Pada Mata Pelajaran Ilmu Pengetahuan Alam di Sekolah Dasar Negeri Setia Dharma 03 Thanbun Selatan

Setyosari, Punaji. 2010. Metode Penelitian Pendidikan dan Pengembangan. Malang: Kencana

Sadiman, Arief S \& Dkk. 2010. Media Pendidikan, Pengertian, Pengembangan, dan Pemanfaatannya. Cetakan ke-14. Jakarta: Rajawali Pers

Sanjaya, Wina. 2008. Perencanaan dan Desain Sistem Pembelajaran. Jakarta : Kencana

Sudjana. 2005. Metoda Statistik. Bandung: Tarsito

Sugiyono. 2009. Metode Penelitian Pendidikan Pendekatan Kuantitatif, Kualitatif, dan $R \& D$. Bandung: Alfabeta 